\title{
30. DISTRIBUTION OF CHAETOCEROS RESTING SPORES IN THE QUATERNARY SEDIMENTS FROM LEG $111^{1}$
}

\author{
Dean A. Stockwell ${ }^{2}$
}

\begin{abstract}
During Leg 119 of the Ocean Drilling Program (ODP), Quaternary sediments of the Southern Ocean were examined for the presence and abundance of Chaetoceros resting spores. Six drill sites were occupied along the Kerguelen Plateau. An additional five drill sites were clustered within Prydz Bay, Antarctica. Chaetoceros resting spores were present at all sites examined. These resting spore assemblages were comprised primarily of Chaetoceros neglectus and several unidentified Chaetoceros species. Resting spore assemblages accounted for approximately $20 \%$ of the total diatom assemblage (ranging from $0 \%$ to $91.4 \%$ of any given sample).

Quantitative estimates of resting spores demonstrated considerable downcore abundance fluctuations, ranging from 0 to $1.82 \times 10^{9}$ valves $/ \mathrm{g}$ sediment. The highest spore production rates $\left(3.75 \times 10^{12} \mathrm{spores} / \mathrm{cm}^{2} / \mathrm{yr}\right)$ were found on the northern Kerguelen Plateau (Sample 119-736B-1H-3, 35-37 cm). A lack of adequate chronological control at all sites prevented proper between-core comparisons. Mean resting spore abundance, however, appeared highest within the sediments of Prydz Bay and across the northern Kerguelen Plateau. Deep-water stations of the southern Kerguelen Plateau demonstrated the lower spore abundances and a reduction in the percentage contribution of spore to the total diatom assemblage.
\end{abstract}

\section{INTRODUCTION}

Diatom resting spore assemblages generally account for a major fraction of the opaline sediments within regions of coastal upwelling (Calvert, 1966; Richert, 1976; Schuette and Schrader, 1979; DeVries and Schrader 1981; Stockwell and Hargraves, 1988). The distribution patterns of spore abundances within surface sediments off Peru and southwest Africa are thought to reflect the geographically fluctuating nutrient fields associated with episodic upwelling within local surface waters (Schuette and Schrader, 1981). Similarly, the occurrence of large numbers of Chaetoceros resting spores has generally been interpreted as being indicative of high primary production (Donegan and Schrader, 1972). In the polar waters of the Southern Hemisphere, however, few endemic spore formers are reported (Hargraves and French, 1983). Even less is known about their abundances and distributions within sediments throughout the Southern Ocean.

Leg 119 of the Ocean Drilling Program (ODP) occupied 11 sites within the Southern Ocean, along the Kerguelen Plateau and south to Prydz Bay, Antarctica. The collection of these materials offered an opportunity to appraise Southern Ocean sediments for the presence of diatom resting spores with respect to time. This paper serves to document the occurrence and abundance of Chaetoceros resting spores from within the Quaternary sediments of these drill sites. The Quaternary was initially chosen, being a period of several cold/warm cycles (Donahue, 1970), with the hope that spore abundances would reflect productivity oscillations.

\section{METHODS}

Materials for this study (Table 1) were obtained from ODP Leg 119. The upper $30 \mathrm{~m}$ of 14 drill sites were examined for the presence and abundance of Chaetoceros resting spores. Sedi-

\footnotetext{
${ }^{1}$ Barron, J., Larsen, B., et al., 1991. Proc. ODP, Sci. Results, 119: College Station, TX (Ocean Drilling Program).

2 Marine Science Institute, P.O. Box 1267, The University of Texas at Austin, Port Aransas, TX 78373-1267, U.S.A.
}

Table 1. Core intervals from which spore samples were examined and generalized site information.

\begin{tabular}{|c|c|c|c|c|c|}
\hline $\begin{array}{l}\text { Core intervals } \\
\text { examined }\end{array}$ & $\begin{array}{c}\text { Sedimentation } \\
\text { rates } \\
(\mathrm{m} / \mathrm{m} . \mathrm{y} .)\end{array}$ & $\begin{array}{l}\text { Age } \\
\text { depth } \\
\text { (Ma) }\end{array}$ & $\begin{array}{l}\text { Sample } \\
\text { depth } \\
\text { (mbsf) }\end{array}$ & $\begin{array}{l}\text { Water } \\
(\mathrm{m})\end{array}$ & $\begin{array}{c}\text { Diatom } \\
\text { zone }\end{array}$ \\
\hline $\begin{array}{c}119-736 \mathrm{~A}-1 \mathrm{H} \text { through } \\
119-736 \mathrm{~A}-16 \mathrm{H}\end{array}$ & 86 & 1.58 & 117.5 & 629.0 & ${ }^{\mathrm{a}} \mathrm{A},{ }^{\mathrm{b}} \mathrm{B}$ \\
\hline $\begin{array}{c}119-736 \mathrm{~B}-1 \mathrm{H} \text { through } \\
119-736 \mathrm{~B}-3 \mathrm{H}\end{array}$ & 86 & 0.62 & 27.1 & 629.0 & A \\
\hline $\begin{array}{c}119-737 \mathrm{~A}-1 \mathrm{H} \text { through } \\
119-737 \mathrm{~A}-1 \mathrm{H}\end{array}$ & 20 & - & 14.5 & 564.0 & A \\
\hline $\begin{array}{c}119-738 \mathrm{~B}-1 \mathrm{H} \text { through } \\
119-738 \mathrm{~B}-2 \mathrm{H}\end{array}$ & 2 & 0.42 & 13.5 & 2252.7 & B \\
\hline $\begin{array}{c}119-739 \mathrm{~A}-1 \mathrm{H} \text { through } \\
119-739 \mathrm{~A}-2 \mathrm{CC}\end{array}$ & 19 & 5.30 & 5.6 & 412.4 & A \\
\hline $\begin{array}{c}119-739 \mathrm{C}-1 \mathrm{R} \text { through } \\
119-739 \mathrm{C}-1 \mathrm{CC}\end{array}$ & 19 & - & 9.5 & 412.4 & A \\
\hline $\begin{array}{c}119-740 \mathrm{~A}-1 \mathrm{R} \text { through } \\
119-740 \mathrm{~A}-3 \mathrm{R}\end{array}$ & - & 0.62 & 23.2 & 807.5 & A \\
\hline $\begin{array}{c}119-740 \mathrm{~B}-1 \mathrm{R} \text { through } \\
119-740 \mathrm{~B}-4 \mathrm{R}\end{array}$ & - & 0.62 & - & 807.5 & A \\
\hline $\begin{array}{c}119-741 \mathrm{~A}-1 \mathrm{R} \text { through } \\
119-741 \mathrm{~A}-4 \mathrm{R}\end{array}$ & - & - & 33.5 & 551.4 & A \\
\hline $\begin{array}{l}119-742 \mathrm{~A}-1 \mathrm{R} \text { through } \\
119-742 \mathrm{~A}-2 \mathrm{R}\end{array}$ & - & 0.62 & 14.1 & 415.7 & A \\
\hline $\begin{array}{c}119-744 \mathrm{~A}-1 \mathrm{H} \text { through } \\
119-744 \mathrm{~A}-1 \mathrm{CC}\end{array}$ & 4.6 & 0.62 & 4.2 & 2307.3 & A, B \\
\hline $\begin{array}{l}119-744 \mathrm{~B}-1 \mathrm{H} \text { through } \\
119-744 \mathrm{~B}-1 \mathrm{CC}\end{array}$ & 4.6 & 0.62 & 9.5 & 2307.3 & A, B \\
\hline $\begin{array}{c}119-745 \mathrm{~A}-1 \mathrm{H} \text { through } \\
119-745 \mathrm{~A}-1 \mathrm{CC}\end{array}$ & 58 & 0.42 & 10.5 & 4082.5 & A \\
\hline $\begin{array}{l}119-745 \mathrm{~B}-1 \mathrm{H} \text { through } \\
119-745 \mathrm{~B}-4 \mathrm{H}\end{array}$ & 58 & 0.42 & 33.5 & 4082.5 & A \\
\hline
\end{tabular}

a Thalassiosira lentiginosa zone used by Ciesielski (1983).

b Thalassiosira lentiginosa zone used by Ciesielski (1983).
Coscinodiscus elliptopora/Actinocyclus ingens zone used by Ciesielski (1983).

ment samples were oven dried for $24 \mathrm{hr}$ at $60^{\circ} \mathrm{C}$. The dry weight of each sample was measured. The samples were acid cleaned and repeatedly washed with deionized water. Slide preparations followed the sedimentation procedures of Battarbee (1973), with modifications suggested by Schrader (1974), Schrader and Gersonde (1978), and Laws (1983). Sedimentation concentrations were adjusted to represent known amounts of sediment per slide 
and counts adjusted to yield valves/gram sediment. Both light and electron microscope observations were made from this processed material.

Counts were made on a Nikon Model SE light microscope at a magnification of $650 \times$, with the counting procedures following those described by Stockwell and Hargraves (1986). Resting spore abundances were enumerated and their relative contribution to the total diatom assemblage documented. All counts were presented as valves per gram of sediment. Adjusted spore abundances were calculated using estimated sedimentation rates (Barron, Larsen, et al., 1989) and measured dry-bulk sediment densities (Barron, Larsen, et al., 1989). These adjusted abundances in turn served as an estimate of resting spore productivity within each core (i.e., given as valves $/ \mathrm{cm}^{2} / \mathrm{yr}$ ).

Quaternary sediments were initially chosen in order to follow changes in spore abundance with respect to the several cold/ warm cycles reported during this time frame (Donahue 1970). Due to a combination of factors (i.e., a lack in adequate age controls, differential preservation, and between-site differences in terrigenous and carbonate loadings), a mean abundance value was calculated for each site.

Ancillary productivity data and resting spore observations from water column samples (Barron, Larsen, et al., 1989) and sediment trap materials (Biggs et al., 1989) were used for water column comparisons. In addition, the percent contribution of Nitzschia kerguelensis to the total diatom assemblage was examined, as a rough estimate of sea-ice environments (Burckle et al., 1987).

\section{RESULTS}

Table 2 summarizes estimated abundance distributions for total spores and total diatoms per gram of sediment. In addition, the percent contribution of total Chaetoceros resting spores to total diatom abundance is shown. Percent contributions of Nitzschia kerguelensis and total pennates are also presented. Raw counts, sedimentation rates, bulk densities, and approximate age of each sample are given in the Appendix.

\section{Site 736}

Site 736 is located about $40 \mathrm{nmi}$ east of Kerguelen Island on the northern edge of the Kerguelen-Heard Plateau in a water depth of approximately $630 \mathrm{~m}$. Diatoms were abundant in all materials examined from Site 736 and preservation was, in general, good. Sedimentation rates for the intervals examined here were estimated at $86 \mathrm{~m} / \mathrm{m}$.y. (Barron, Larsen, et al., 1989). All diatomaceous material examined from Hole 736A (to a depth of about $113 \mathrm{~m}$ below seafloor) was younger than $1.58 \mathrm{Ma}$. Be- cause of incomplete recovery of sediments in the uppermost sediments of Hole 736A, a second coring site was occupied. Recovery at Hole 736B was $20 \mathrm{~m}$ with all spore materials younger than $0.62 \mathrm{Ma}$.

Combining both cores, 100 samples were examined for their spore assemblages. Total diatoms averaged $1.95 \times 10^{8}$ valves $/ g$ sediment for both cores. Mean diatom abundances, however, in Hole 736B appeared three times greater than the diatom quantities in the uppermost sections of Hole 736A. The percent contribution of Chaetoceros resting spores to total diatoms also shifted from $20 \%$ at Hole $736 \mathrm{~B}$ to about $5.5 \%$ at Hole $736 \mathrm{~A}$. Both spore assemblages were comprised of Chaetoceros neglectus, Chaetoceros sp. A, and Chaetoceros sp. B.

Adjusting for sedimentation rate and bulk densities, Site 736 yielded $5.01 \times 10^{11}$ diatoms $/ \mathrm{cm}^{2} / \mathrm{yr}$, of which $13.8 \%$ were spores. The highest spore abundances were found within Hole $736 \mathrm{~B}$ cores, reaching a maximum adjusted value of $3.75 \times 10^{12}$ spores $/ \mathrm{cm}^{2} / \mathrm{yr}$ at approximately $0.4 \mathrm{Ma}$. Nitzschia kerguelensis forms $34.8 \%$ of the total diatom abundance, whereas all pennates combined were $47.6 \%$.

\section{Site 737}

Site 737 is located $100 \mathrm{~km}$ southeast of Site 736 , also on the northern edge of the Kerguelen Plateau, in a water depth of $564 \mathrm{~m}$. Quaternary sediments at Site 737 were confined to the upper 1.5 $\mathrm{m}$ of the core. Within this narrow band diatom abundances fluctuated considerably as did preservation. Adjusted diatom abundances were comparable to those at Site 736 , at $1.47 \times$ $10^{11}$ diatoms $/ \mathrm{cm}^{2} / \mathrm{yr}$. The spore assemblages were similar in composition to Site 736 , with the percentage contribution increasing to $20.2 \%$ of all diatoms. The relative proportion of spores to total diatoms was remarkably similar between Hole 736B and Site 737 , despite a difference to mean diatom abundance. Although the relative abundances of pennate diatoms were similar between these two northern Kerguelen Sites, the percentage contribution of Nitzschia kerguelensis dropped by half, to about $18 \%$.

\section{Site 738}

Situated on the southern Kerguelen Plateau, Site 738 was drilled in $2252.7 \mathrm{~m}$ of water. The upper $13.5 \mathrm{~m}$ of Hole $738 \mathrm{~B}$ was estimated to be less than $3.9 \mathrm{Ma}$ old with a sedimentation rate of $2 \mathrm{~m} / \mathrm{m}$.y. Spore assemblages in both Cores $119-738 \mathrm{~B}-1 \mathrm{H}$ and 119-738B-2H were again dominated by Chaetoceros neglectus and Chaetoceros sp. A. Core 119-738B-1H, the bottom of which is $0.42 \mathrm{Ma}$ old, averaged $1.1 \%$ spores. Diatoms were well preserved in these samples and averaged $1.08 \times 10^{9}$ valves $/ g$ sediment. Pennates dominated these sediments at $80.1 \%$, with

Table 2. Mean values for diatom and spore abundances. Adjusted means utilize sediment density and sedimentation rates. Percentage contribution to total diatoms of spores, Nitzschia kerguelensis (N. k.), and pennates is also given.

\begin{tabular}{|c|c|c|c|c|c|c|c|}
\hline \multirow[b]{3}{*}{ Site } & \multirow{3}{*}{$\begin{array}{c}\text { Mean } \\
\text { Diatom total } \\
\left(\text { cells } \times 10^{8} \mathrm{gm}^{-1}\right)\end{array}$} & \multicolumn{2}{|c|}{ Adjusted mean } & \multirow[b]{3}{*}{ Spore total } & \multirow[b]{3}{*}{ Spores } & \multirow[b]{3}{*}{ N. k. } & \multirow[b]{3}{*}{ Pennates } \\
\hline & & Spore tot & al Diatom total & & & & \\
\hline & & (cells $\times$ & $\left.10^{11} \mathrm{~cm}^{-2} \mathrm{yr}^{-1}\right)$ & & & & \\
\hline $736 \mathrm{~A}$ & 0.904 & 0.059 & 2.894 & 0.186 & 6.3 & 39.2 & 52.0 \\
\hline $736 \mathrm{~B}$ & 2.802 & 1.995 & 6.739 & 4.189 & 19.9 & 31.3 & 43.9 \\
\hline $736 A+B$ & 1.948 & 1.124 & 5.009 & 2.387 & 13.8 & 34.8 & 47.6 \\
\hline $737 \mathrm{~A}$ & 1.474 & 0.143 & 1.474 & 0.143 & 20.2 & 18.4 & 56.0 \\
\hline $738 \mathrm{~B}$ & 0.823 & 0.007 & 0.114 & 0.001 & 0.8 & 19.7 & 78.2 \\
\hline 739A & 0.034 & 0.013 & 0.143 & 0.053 & 34.0 & 18.6 & 51.5 \\
\hline $740 \mathrm{~A}$ & 6.833 & 1.510 & - & - & 23.7 & 0.9 & 57.3 \\
\hline $741 \mathrm{~A}$ & 3.058 & 0.258 & - & - & 8.6 & 6.1 & 82.2 \\
\hline $742 \mathrm{~A}$ & 0.229 & 0.048 & - & - & 33.1 & 6.7 & 43.0 \\
\hline $744 \mathrm{~A}$ & 3.390 & 0.016 & 74.748 & 0.325 & 0.4 & 41.4 & 44.6 \\
\hline $744 \mathrm{~B}$ & 1.875 & 0.010 & 49.910 & 0.260 & 0.4 & 31.5 & 66.6 \\
\hline $744 A+B$ & 2.362 & 0.012 & 57.882 & 0.281 & 0.4 & 43.7 & 55.6 \\
\hline 745 & 1.667 & 0.029 & 4.401 & 0.077 & 2.0 & 49.7 & 73.1 \\
\hline
\end{tabular}


Nitzschia kerguelensis comprising about half of this number. Within Core 119-738B-2H, diatom and spore abundances dropped. Resting spores made up only $0.6 \%$ of the total diatoms (averaging $6.5 \times 10^{8}$ diatoms/g sediment). Similarly, the percent contribution of Nitzschia kerguelensis dropped from $40 \%$ to $5.8 \%$ of the total diatoms.

Compared with the northern Kerguelen Sites, Site 738 showed a marked reduction in sedimentation rates. Mean adjusted diatom abundances were also lower, on the order of $1.1 \times 10^{10}$ diatoms $/ \mathrm{cm}^{2} / \mathrm{yr}$ were, in contrast to the increased proportion of pennates.

\section{Site 739}

Site 739 is one of the five sites Leg 119 occupied in Prydz Bay. The site is situated on the outer boundaries of the bay, in a water depth of only $421 \mathrm{~m}$. Sediments in the upper $20 \mathrm{~m}$ of the core appeared Quaternary in age, but proper biostratigraphic controls were not present for age determination. This site yielded the lowest mean diatom abundances for the nine sites examined $\left(3.44 \times 10^{6}\right.$ cells $/ g$ sediment). Of the total diatom assemblage, $85 \%$ of cells were made up of the combination of spores $(34 \%)$ and pennates $(51.5 \%)$.

\section{Site 740}

In a water depth of $807.5 \mathrm{~m}$, Site 740 constitutes the innermost of the two inner Prydz Bay stations. Quaternary samples were estimated to be younger than $0.62 \mathrm{Ma}$, but sedimentation rates again could not be determined. Diatom assemblages varied from abundant and well-preserved to sparse and poorly preserved. The mean value for diatom abundance, however, was the highest of all stations examined, at $6.83 \times 10^{8}$ diatoms $/ g$ sediment. Chaetoceros resting spores accounted for $20 \%$ of the total diatom assemblage. Chaetoceros neglectus and Chaetoceros sp. A again dominated the spore assemblage. Vegetative valves from Chaetoceros dichaeta and Chaetoceros atlanticum f. bulbosum were also commonly found. Typically, pennates accounted for $52 \%$ of the all diatom valves.

\section{Site 741}

Site 741 was occupied in a water depth of $551.4 \mathrm{~m}$ and is the outermost of the inner Prydz Bay stations. Diatoms were observed only in the upper $30 \mathrm{~m}$ of this core, with diatom abundances ranging from 0 to $4.45 \times 10^{8}$ frustules $/ \mathrm{g}$ sediment. Preservation varied from poor to good, with considerable breakage typical. As with Site 740, a lack of microfossils disallowed an estimate of sedimentation rates. In diatom-bearing samples, pennates comprised about $82 \%$ of the total cells. Nitzschia cylindrus, Nitzschia kerguelensis, Nitzschia curta, and Nitzschia ritscheri were some of the dominant forms present. Spore assemblages made up less than $10 \%$ of these diatom assemblages. Of the spores, once again Chaetoceros neglectus and Chaetoceros sp. A dominated the spore assemblage.

\section{Site $\mathbf{7 4 2}$}

Quaternary sediments were restricted to the upper $4.5 \mathrm{~m}$ of this $316 \mathrm{~m}$ core, with a maximum age of $0.62 \mathrm{Ma}$. In $415 \mathrm{~m}$ of water, sediment from this outer Prydz Bay station lacked the necessary microfossils for the determination of sedimentation rates. Diatom abundances ranged from rare to $5.8 \times 10^{7}$ valves/ $\mathrm{g}$ sediment. Again because of the lack of chronological control, sedimentation rates were not available. Of those sediments bearing diatoms, the Chaetoceros spore assemblage occupied 33\% of total cells, matching the $34 \%$ of Site 739 . Thus, the two outer Prydz Bay Sites appeared to have relatively more spores, while also having lower total diatoms, than the two inner Prydz Bay sites. The sediments were again pennate rich, comprising $43 \%$ of total cells.

\section{Site 743}

No spore samples were taken from this outermost Prydz Bay site because of the poor diatom abundance and preservation. The lack of sedimentation rates did not allow for calculating an adjusted diatom abundance. Total cell numbers/gm sediment were, therefore, compared. Diatoms were most abundant at the two inner Prydz Bay stations. Chaetoceros resting spores averaged roughly $25 \%$ of the total diatom assemblage with pennates at almost $60 \%$. Although maximum diatom numbers were present in Prydz Bay, maximum spore abundances were found at the north Kerguelen sites. Similarly, maximum numbers of Nitzschia kerguelensis were also found to the north at the southern and eastern Kerguelen Sites.

\section{Site 744}

The second southern Kerguelen Plateau site includes Holes $744 \mathrm{~A}$ and $744 \mathrm{~B}$. At this deep-water site $(2307.3 \mathrm{~m})$, sediments within the upper $9.5 \mathrm{~m}$ were estimated to be younger than 0.65 Ma. Sedimentation rates of $4.6 \mathrm{~m} / \mathrm{m}$.y. were slightly higher than the estimates for Site 738. Diatoms were, in general, well preserved and abundant. Mean diatom abundances for Hole 744A $\left(3.39 \times 10^{8}\right.$ valves $/ g$ sediment) were approximately twice that of Hole 744B $\left(1.88 \times 10^{8}\right.$ frustules/g sediment $)$. The relative numbers of spores and total pennates to total diatoms remained about the same. Variability of within-site comparisons in absolute diatom numbers is as great as between-site comparison. Chaetoceros resting spores appeared consistently less than $0.5 \%$ at these sites. Nitzschia kerguelensis dominated a uniformly pennate-rich sediment.

\section{Site 745}

Site 745, the deepest of the sites occupied during Leg 119 (water depth of $4093 \mathrm{~m}$ ), is situated on a sediment ridge along the southeast slope of the Kerguelen Plateau. The sediments examined were younger than $0.55 \mathrm{Ma}$. Diatoms were abundant and well preserved. Samples from both Holes $745 \mathrm{~A}$ and $745 \mathrm{~B}$ were found to yield mean adjusted diatom abundances of 4.40 $\times 10^{11}$ valves $/ \mathrm{cm} / \mathrm{yr}$. Resting spores formed a modest $2 \%$ of these valves. Nitzschia kerguelensis, however, comprised almost $50 \%$ of total diatom frustules found. Both sites 744 and 745 produced the highest maximum numbers of Nitzschia kerguelensis.

\section{DISCUSSION}

Diatom content, abundance, and preservation varied considerably within these sediments, as a function of both age and location. Such fluctuations are thought to reflect changes in sedimentological and environmental regimes through time (Schrader, 1976). In addition, diatom preservation and abundance in sediments is thought to accurately reflect annual productivity in the overlying water column (Burckle, 1984). Diatom resting spores also appeared abundantly throughout the Quaternary sediments of the Kerguelen Plateau and Prydz Bay. Figure 1 illustrates comparisons in mean diatom abundance, mean percent contribution of resting spores, and mean percentage pennate diatoms by site. Sediment of the inner Prydz Bay sites demonstrated the highest absolute diatom abundances, $1.73 \times 10^{13}$ valves/g sediment. Lowest abundances were found immediately to the north at the outer Prydz Bay sites. Typically accounting for $20 \%$ of the total diatom assemblage, spore assemblages at times comprised $91 \%$ of the diatom component. Lowest spore percentages, typically less than $5 \%$, appeared in the deep-water stations on the southern Kerguelen Plateau.

The spore assemblages were primarily dominated by spores of Chaetoceros neglectus (PI. 1) and an unknown Chaetoceros species, sp. A ( $\mathrm{Pl}$. 2). These two spores were found by the author in surface sediments from the Ross Sea, from the Brans- 


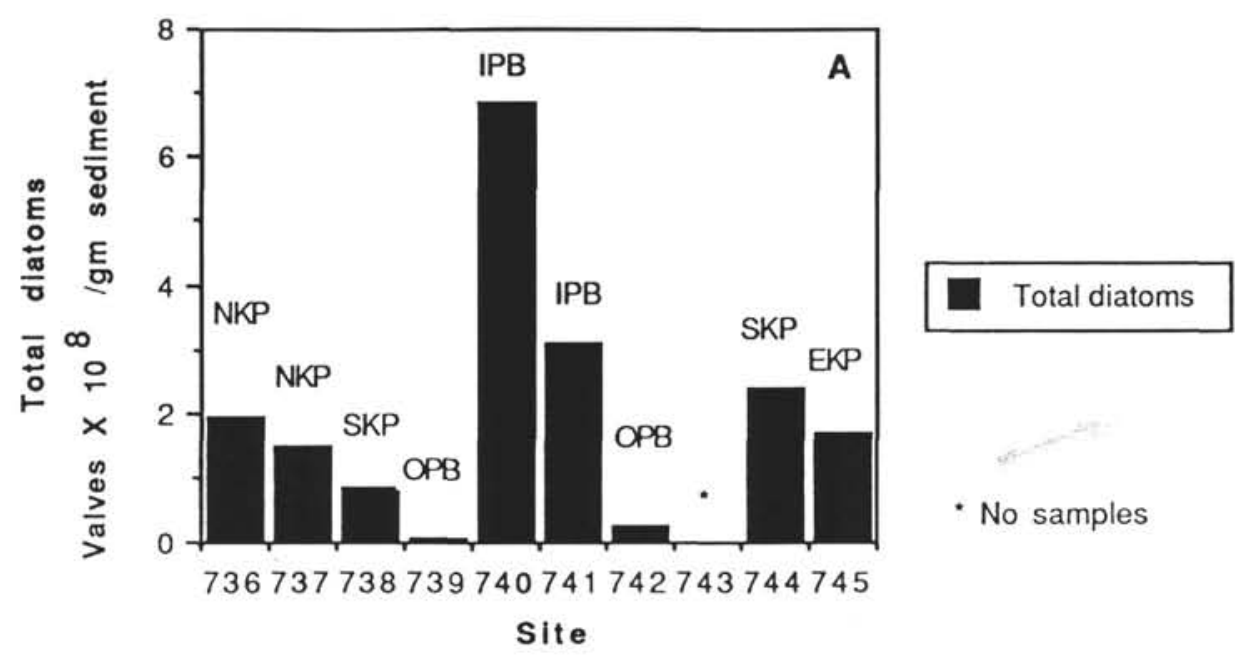

ODP LEG-119: MEAN \% CONTRIBUTION BY SPORES
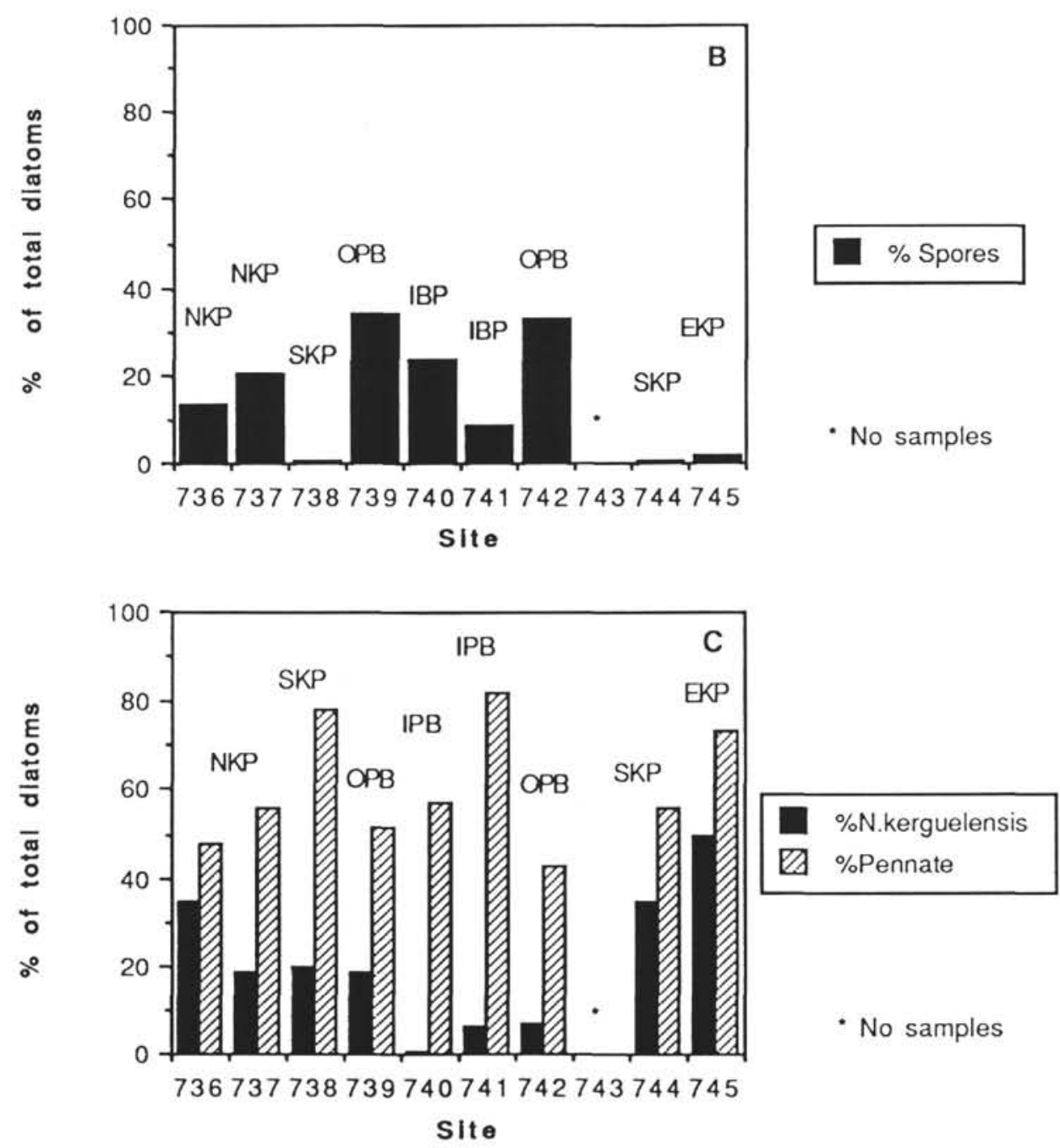

Figure 1. Comparisons of mean core values, by site. NKP = North Kerguelen Plateau; SKP = South Kerguelen Plateau; IPB = Inner Prydz Bay; OPB = Outer Prydz Bay; EKP = Eastern Kerguelen Plateau. A. Mean diatom and resting spore abundances. B. Mean percentage contribution of Chaetoceros resting spores to the total diatom assemblage. C. Mean percentage contribution of pennate diatoms and Nitzschia kerguelensis to total diatom valves. 
field Strait, and from the Weddell Sea. Their overall distribution appears circumpolar. Other Chaetoceros species occur in lesser numbers within these sediments, but their specific affinities are as yet undetermined (Pls. 3 and 4). The sediments appeared to be primarily pennate dominated, with a pennate component of $40 \%-80 \%$ of the total assemblage. The reduction in the percentage of Nitzschia kerguelensis to total diatoms, within Prydz Bay, suggests a sea-ice controlled environment (Burckle, et al., 1987), yet resting spore related species are able to maintain high abundances. Within this study no direct or simple correlation between the distributions of spore numbers and other species was evident.

Figure 2A illustrates a ranking of total diatom abundances and the relative contributions of resting spores, by site. Resting spores appeared most numerous within the sediments of Prydz Bay and across the northern Kerguelen Plateau. Figure 2B further depicts a trend of high productivity over the northern Kerguelen Plateau, increasing slightly to the southern Kerguelen Plateau, declining in the vicinity of outer Prydz Bay, and then increasing again within Prydz Bay. Surface chlorophyll data trends further tend to substantiate this pattern (Barron, Larsen, et al., 1989). Spore numbers are greatly reduced in the deeper waters over the southern Kerguelen Plateau. It should be noted that several collections of living phytoplankton made over these sites contained Chaetoceros neglectus-bearing resting spores (personal observation). Fecal pellets from euphausiids and copepods also were laden with similar spores, as well as numerous pennate forms (Barron, Larsen, et al., 1989). Most centric forms appear highly fragmented within these pellets (personal observation). Such packaging would facilitate a more rapid sedimentation of spore forms and pennate diatoms.

\section{SUMMARY AND CONCLUSIONS}

Resting spores of the marine diatom genus Chaetoceros Ehr. commonly occur throughout the Quaternary sediments of the Southern Ocean. Large numbers of spores, of relatively few species, can periodically dominate water column assemblages, zooplankton fecal pellets, and the underlying sediments. Spore abundances fluctuate both within and between drill sites. These Chaetoceros spores appear circumpolar in distribution, with Chaetoceros neglectus a common dominant. At least two other Chaetoceros species are commonly represented in the sediments by their resting spores, their specific affinities yet to be determined.

Diatom resting spores were found to be common not only in the sediments of near-shore waters, but were found to reach maximum numbers over the northern Kerguelen Plateau. Again, these resting spore distributions appear to follow the general trends in primary productivity patterns indicated by chlorophyll distributions. The high supply rates, high sedimentation rates, and stronger silicification of spores endow the sediments with a productivity record of the more delicate Chaetoceros vegetative forms from which they are formed. Chaetoceros species have widespread distributions throughout the Southern Ocean. Further work on those factors initiating resting spore formation in nutrient-rich polar waters and subsequent spatial distributions is needed for further evaluation.

\section{ACKNOWLEDGMENTS}

This research was supported by a NSF/JOI grant funded through TAMRF Project \#6077, TAMRF PO 20202. I thank Dr. Greta Fryxell for her most valuable assistance, technical support, and precious time. I would also like to thank Norzani
Mufti for help in sampling the preparation. A special thanks also goes to Jack Baldauf, John Barron, and the three anonymous reviewers for their helpful criticisms in the preparation of this manuscript. In particular, I would like to express my greatest regards for the captain, officers, and crew of the ice-support vessel Maersk Master for an outstanding job.

\section{REFERENCES}

Barron, J., Larsen, B., et al., 1989. Proc. ODP, Init. Repts., 119: College Station, TX (Ocean Drilling Program).

Battarbee, R. W., 1973. A new method for the estimation of absolute microfossil numbers, with reference especially to diatoms. Limnol. Oceanogr., 18:647-653.

Burckle, L. H., Jacobs, S. S., and McLaughlin, R. B., 1987. Late austral spring diatom distribution between New Zealand and the Ross Ice Shelf, Antarctica: hydrographic and sediment correlations. $\mathrm{Mi}$ cropaleontology, 33:74-81.

Calvert, S. E., 1966. Accumulation of diatomaceous silica in sediments of the Gulf of California. Geol. Soc. Am. Bull., 77:569-596.

Ciesielski, P. F., 1983. The Neogene and Quaternary diatom biostratigraphy of subantarctic sediments, Deep Sea Drilling Project Leg 71. In Ludwig, W. J., Krasheninnikov, V. A., et al., Init. Repts. DSDP, 71 (Pt. 2): Washington (U.S. Govt. Printing Office), 635-666.

DeVries, T. J., and Schrader, H., 1981. Variations of upwelling/oceanic conditions during the latest Pleistocene through Holocene off the central Peruvian coast: a diatom record. Mar. Micropaleontol., 6: 157-167.

Donahue, J. G., 1970. Pleistocene diatoms as climatic indicators in North Pacific sediments. Mem. Geol. Soc. Am., 126:121-138.

Donegan, D., and Schrader, H., 1972. Biogenic and abiogenic components of laminated hemipelagic sediments in the central Gulf of California. Mar. Geol., 48:215-237.

Hargraves, P. E., and French, F. W., 1983. Diatom resting spores: significance and strategies. In Fryxell, G. A. (Ed.), Survival Strategies of the Algae: Cambridge (Cambridge Univ. Press), 49-68.

Laws, R. A., 1983. Preparing strewn slides for quantitative microscopical analysis: a test using calibrated microspheres. Micropaleontology, 29:60-65.

Richert, P., 1976. Relationship between diatom biocoenoses and taphocoenoses in upwelling areas off West Africa. 4th Symposium on Recent and Fossil Diatoms, Oslo. (Abstract)

Schrader, H., 1974. Proposal for a standardized method of cleaning diatom bearing deep-sea and land-exposed marine sediments. Nova Hedwigia Beih., 45:403-409.

Schrader, H.-J., 1976. Cenozoic planktonic diatom biostratigraphy of the Southern Pacific Ocean. In Hollister, C. D., Craddock, C., et al., Init. Repts. DSDP, 35: Washington (U.S. Govt. Printing Office), 605-672.

Schrader, H. J., and Gersonde, R., 1978. Diatoms and silicoflagellates. Utrecht Micropaleontol. Bull., 17:129-176.

Schuette, G., and Schrader, H., 1979. Diatom taphocoenoses in the coastal upwelling area off western South America. Nova Hedwigia Beih., 64:359-378.

1981. Diatoms in surface sediments: a reflection of coastal upwelling. In Richards, F. A. (Ed.), Coastal Upwelling: Am. Geophys. Union, 372-380.

Stockwell, D. A., and Hargraves, P. E., 1986. Morphological variability within resting spores of the marine diatom genus Chaetoceros Ehrenberg. In Ricard, M. (Ed.), Proc. 8th Inter. Diatom Symp., Paris, August 27-September 1, 1984, 81-96.

1988. Distribution and size variation of resting spores in Chaetoceros radicans and Chaetoceros debilis within the diatomaceous muds of the Guaymas Basin and Guaymas Basin Slope, Gulf of California. In Round, F. E. (Ed.), Proc. 9th Inter. Diatom Symp., Bristol, August 24-30, 1986, 219-231.

Date of initial receipt: 2 January 1990

Date of acceptance: 12 July 1990

Ms 119B-156 

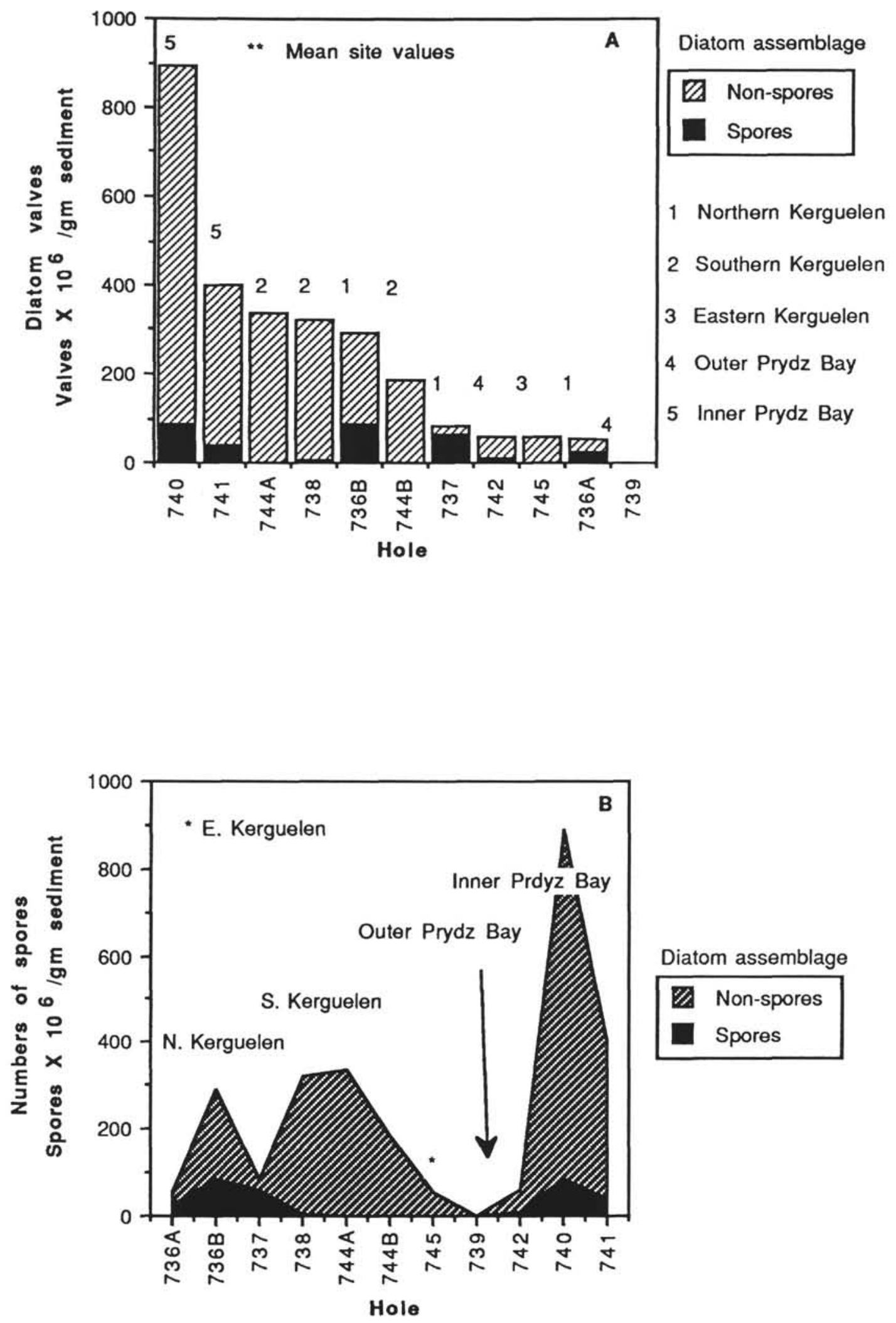

Figure 2. Site comparisons. A. Sites ranked by diatom abundances. The relative contributions of Chaetoceros resting spores are also shown. B. Regional distribution of diatom and resting spore abundances illustrated by site. Values represent means for each core examined. 
APPENDIX

Sample listing, raw diatom counts, and sample information. S.R. = sedimentation rates, D. = bulk density.

\begin{tabular}{|c|c|c|c|c|c|c|c|c|c|}
\hline \multirow{2}{*}{$\begin{array}{l}\text { Hole, core, section, } \\
\text { interval }(\mathrm{cm})\end{array}$} & \multirow[b]{2}{*}{ Zone } & \multicolumn{4}{|c|}{ Counts $\times 10^{7}$} & \multirow[b]{2}{*}{ S.R. } & \multirow[b]{2}{*}{ D. } & \multirow{2}{*}{$\begin{array}{l}\text { Depth } \\
\text { (mbsf) }\end{array}$} & \\
\hline & & Spores & Centrics & Pennates & Diatoms & & & & (m.y.) \\
\hline $736 \mathrm{~A}-1 \mathrm{H}-4,93-95$ & 1 & 2.456 & 1.278 & 1.585 & 5.318 & 86 & 0.23 & 5.44 & 0.06 \\
\hline $1 \mathrm{H}-4,137-139$ & 1 & 0.020 & 0.373 & 0.521 & 0.913 & 86 & 0.48 & 5.88 & 0.07 \\
\hline $1 \mathrm{H}-5,40-42$ & 1 & 0.066 & 1.121 & 1.042 & 2.229 & 86 & 0.48 & 6.41 & 0.07 \\
\hline $1 \mathrm{H}-5,93-95$ & 1 & 0.404 & 1.201 & 1.514 & 3.119 & 86 & 0.48 & 6.94 & 0.08 \\
\hline 1H-5, 137-139 & 1 & 0.165 & 2.036 & 2.633 & 4.834 & 86 & 0.48 & 7.38 & 0.09 \\
\hline $1 \mathrm{H}-6,40-42$ & 1 & 0.063 & 1.209 & 1.485 & 2.473 & 86 & 0.51 & 7.91 & 0.09 \\
\hline $1 \mathrm{H}-6,93-95$ & 1 & 0.030 & 0.960 & 1.019 & 2.009 & 86 & 0.51 & 8.44 & 0.10 \\
\hline $1 \mathrm{H}-6,130-132$ & 1 & 0.019 & 1.371 & 1.768 & 3.157 & 86 & 0.51 & 8.81 & 0.10 \\
\hline $2 \mathrm{H}-1,40-42$ & 1 & 0.085 & 1.059 & 3.208 & 4.351 & 86 & 0.23 & 9.41 & 0.11 \\
\hline $2 \mathrm{H}-1,90-92$ & 1 & 0.069 & 1.445 & 1.231 & 2.746 & 86 & 0.23 & 9.91 & 0.12 \\
\hline $2 \mathrm{H}-1,140-142$ & 1 & 0.049 & 1.700 & 0.696 & 2.444 & 86 & 0.23 & 10.41 & 0.12 \\
\hline $2 \mathrm{H}-2,40-42$ & 1 & 0.158 & 2.570 & 2.089 & 4.816 & 86 & 0.23 & 10.91 & 0.13 \\
\hline $2 \mathrm{H}-2,90-92$ & 1 & 0.643 & 17.799 & 13.349 & 31.790 & 86 & 0.23 & 11.41 & 0.13 \\
\hline $2 \mathrm{H}-2,140-142$ & 1 & 0.508 & 14.485 & 6.988 & 23.633 & 86 & 0.23 & 11.91 & 0.14 \\
\hline $2 \mathrm{H}-3,40-42$ & 1 & 1.304 & 2.568 & 1.797 & 5.669 & 86 & 0.23 & 12.41 & 0.14 \\
\hline $2 \mathrm{H}-4,40-42$ & 1 & 0.445 & 13.975 & 4.510 & 18.930 & 86 & 0.23 & 13.91 & 0.16 \\
\hline $2 \mathrm{H}-4,90-92$ & 1 & 0.185 & 0.671 & 1.806 & 2.663 & 86 & 0.23 & 14.41 & 0.17 \\
\hline $2 \mathrm{H}-4,140-142$ & 1 & 0.338 & 0.640 & 2.146 & 3.124 & 86 & 0.23 & 14.91 & 0.17 \\
\hline $3 \mathrm{H}-1,40-42$ & 1 & 0.241 & 2.279 & 2.065 & 4.586 & 86 & 0.60 & 18.91 & 0.22 \\
\hline $3 \mathrm{H}-1,96-98$ & 1 & 0.047 & 0.779 & 0.653 & 1.478 & 86 & 0.60 & 19.47 & 0.23 \\
\hline $3 \mathrm{H}-1,137-139$ & 1 & 0.091 & 0.942 & 0.868 & 1.900 & 86 & 0.60 & 19.88 & 0.23 \\
\hline $3 \mathrm{H}-2,40-42$ & 1 & 0.080 & 1.538 & 1.259 & 2.877 & 86 & 0.60 & 20.41 & 0.24 \\
\hline $3 \mathrm{H}-2,96-98$ & 1 & 0.077 & 0.992 & 1.273 & 2.343 & 86 & 0.60 & 60.97 & 0.71 \\
\hline $3 \mathrm{H}-2,137-139$ & 1 & 1.022 & 2.151 & 3.197 & 6.370 & 86 & 0.60 & 21.38 & 0.25 \\
\hline $3 \mathrm{H}-3,40-42$ & 1 & 0.151 & 1.207 & 0.887 & 2.245 & 86 & 0.60 & 21.91 & 0.25 \\
\hline $3 \mathrm{H}-3,96-98$ & 1 & 0.041 & 0.625 & 0.716 & 1.382 & 86 & 0.60 & 22.47 & 0.26 \\
\hline $3 \mathrm{H}-4,40-42$ & 1 & 0.135 & 1.066 & 1.208 & 2.410 & 86 & 0.58 & 23.41 & 0.27 \\
\hline $3 \mathrm{H}-4,96-98$ & 1 & 0.106 & 1.613 & 1.580 & 3.299 & 86 & 0.58 & 23.97 & 0.28 \\
\hline $3 \mathrm{H}-4,137-139$ & 1 & 1.727 & 2.896 & 9.755 & 14.379 & 86 & 0.58 & 24.38 & 0.28 \\
\hline $4 \mathrm{H}-1,40-42$ & 2 & 0.102 & 0.426 & 0.674 & 1.202 & 86 & 0.56 & 28.41 & 0.33 \\
\hline $4 \mathrm{H}-1,90-92$ & 2 & 0.404 & 0.808 & 2.557 & 3.775 & 86 & 0.56 & 28.91 & 0.34 \\
\hline $4 \mathrm{H}-1,140-142$ & 2 & 0.079 & 0.683 & 0.736 & 2.007 & 86 & 0.56 & 29.41 & 0.34 \\
\hline $4 \mathrm{H}-2,40-42$ & 2 & 1.330 & 3.069 & 6.990 & 11.388 & 86 & 0.53 & 29.91 & 0.35 \\
\hline $5 \mathrm{H}-3,100-101$ & 2 & 8.355 & 6.060 & 29.474 & 43.889 & 86 & 0.29 & 37.01 & 0.43 \\
\hline $6 \mathrm{H}-3,99-100$ & 2 & 0.000 & 4.528 & 26.038 & 30.566 & 86 & 0.30 & 42.00 & 0.49 \\
\hline $7 \mathrm{H}-3,100-101$ & 2 & 3.506 & 1.818 & 20.256 & 25.579 & 86 & 0.35 & 47.01 & 0.55 \\
\hline $8 \mathrm{H}-1,100-101$ & 2 & 0.011 & 0.638 & 0.375 & 1.024 & 86 & 0.76 & 52.01 & 0.60 \\
\hline $9 \mathrm{H}-3,100-101$ & 2 & 0.021 & 0.364 & 0.263 & 0.648 & 86 & 0.80 & 57.01 & 0.66 \\
\hline $10 \mathrm{H}-3,100-101$ & 2 & 0.329 & 2.631 & 2.314 & 5.261 & 86 & 0.48 & 63.01 & 0.73 \\
\hline $11 \mathrm{H}-3,100-101$ & 2 & 0.067 & 4.285 & 5.892 & 10.244 & 86 & 0.43 & 72.51 & 0.84 \\
\hline $12 \mathrm{H}-3,100-101$ & 2 & 0.369 & 6.635 & 13.822 & 20.825 & 86 & 0.47 & 77.51 & 0.90 \\
\hline $13 \mathrm{H}-3,99-100$ & 2 & 0.000 & 5.251 & 22.755 & 28.006 & 86 & 0.34 & 83.50 & 0.97 \\
\hline $14 \mathrm{H}-3,99-100$ & 2 & 0.157 & 4.311 & 14.814 & 19.282 & 86 & 0.39 & 93.00 & 1.08 \\
\hline $15 \mathrm{H}-3,99-100$ & 2 & 0.000 & 10.451 & 10.094 & 20.545 & 86 & 0.42 & 102.50 & 1.19 \\
\hline $16 \mathrm{H}-3,99-100$ & 2 & 1.133 & 8.237 & 5.582 & 14.935 & 86 & 0.53 & 112.00 & 1.30 \\
\hline $736 \mathrm{~B}-1 \mathrm{H}-1,35-37$ & $\overline{1}$ & 8.735 & 4.230 & 16.261 & 29.225 & 86 & 0.24 & 0.36 & 0.00 \\
\hline $1 \mathrm{H}-1,85-87$ & 1 & 9.385 & 5.284 & 22.949 & 37.617 & 86 & 0.24 & 0.86 & 0.01 \\
\hline $1 \mathrm{H}-1,135-137$ & 1 & 6.455 & 4.910 & 12.634 & 23.999 & 86 & 0.24 & 1.36 & 0.02 \\
\hline $1 \mathrm{H}-2,35-37$ & 1 & 136.365 & 3.976 & 10.204 & 150.545 & 86 & 0.24 & 1.86 & 0.02 \\
\hline $1 \mathrm{H}-2,85-87$ & 1 & 170.737 & 3.234 & 13.581 & 188.522 & 86 & 0.24 & 2.36 & 0.03 \\
\hline $1 \mathrm{H}-2,135-137$ & 1 & 175.964 & 4.523 & 15.380 & 195.867 & 86 & 0.24 & 2.86 & 0.03 \\
\hline $1 \mathrm{H}-3,35-37$ & 1 & 181.741 & 5.061 & 17.484 & 205.206 & 86 & 0.24 & 3.36 & 0.04 \\
\hline $1 \mathrm{H}-3,135-137$ & 1 & 178.489 & 3.292 & 17.056 & 199.907 & 86 & 0.24 & 4.36 & 0.05 \\
\hline $1 \mathrm{H}-4,35-37$ & 1 & 89.102 & 1.956 & 14.343 & 105.619 & 86 & 0.24 & 4.86 & 0.06 \\
\hline $1 \mathrm{H}-4,85-87$ & 1 & 63.621 & 4.028 & 10.426 & 78.075 & 86 & 0.24 & 5.36 & 0.06 \\
\hline $1 \mathrm{H}-4,135-137$ & 1 & 56.342 & 2.183 & 3.153 & 61.678 & 86 & 0.24 & 5.86 & 0.07 \\
\hline $1 \mathrm{H}-3,42-43$ & 1 & 0.062 & 0.049 & 0.146 & 0.257 & $19 ?$ & 1.73 & 3.43 & 0.18 \\
\hline $1 \mathrm{H}-\mathrm{CC}$ & 1 & 0.331 & 0.051 & 0.206 & 0.588 & $19 ?$ & 1.77 & 4.60 & 0.24 \\
\hline $2 \mathrm{H}-1,9-11$ & 1 & 0.101 & 0.078 & 0.156 & 0.334 & $19 ?$ & 1.80 & 4.70 & 0.25 \\
\hline $2 \mathrm{H}-\mathrm{CC}$ & 1 & 0.121 & 0.048 & 0.193 & 0.363 & $19 ?$ & 1.80 & 5.60 & 0.29 \\
\hline $739 \mathrm{C}-1 \mathrm{R}-1,5-7$ & 1 & 0.598 & 0.508 & 3.163 & 4.269 & $19 ?$ & 1.62 & 0.06 & 0.00 \\
\hline 1R-CC & 1 & 0.237 & 0.090 & 0.318 & 0.645 & $19 ?$ & 1.62 & 9.50 & 0.50 \\
\hline $740 \mathrm{~A}-1 \mathrm{R}-1,1-2$ & 1 & 8.614 & 8.614 & 71.905 & 89.132 & & & 0.02 & \\
\hline 1R-1, 70-71 & 1 & 9.506 & 7.828 & 51.163 & 68.496 & & & 0.75 & \\
\hline $2 \mathrm{R}-1,3-4$ & 1 & 15.634 & 9.988 & 19.760 & 45.382 & & & 6.35 & \\
\hline $2 \mathrm{R}-1,52-53$ & 1 & 0.011 & 0.011 & 0.018 & 0.040 & & & 6.53 & \\
\hline $3 R-1,45-46$ & 2 & 18.271 & 13.316 & 40.569 & 72.157 & & & 14.16 & \\
\hline $3 R-2,45-46$ & 2 & 8.109 & 11.887 & 13.361 & 33.357 & & & 16.66 & \\
\hline $3 R-3,45-46$ & 2 & 0.320 & 0.464 & 0.805 & 1.589 & & & 17.16 & \\
\hline 740B-1R-1, 0-3 & 1 & 22.559 & 12.147 & 150.104 & 184.810 & & & 0.02 & \\
\hline $1 \mathrm{R}-1,51-54$ & 1 & 55.643 & 18.002 & 76.918 & 150.562 & & & 0.53 & \\
\hline $4 \mathrm{R}-1,99-102$ & 1 & 12.430 & 6.480 & 18.591 & 37.501 & & & & \\
\hline $4 \mathrm{R}-2,39-40$ & 1 & 0.000 & 0.000 & 0.000 & 0.000 & & & & \\
\hline $4 R-3,37-38$ & 1 & 0.000 & 0.000 & 0.000 & 0.000 & & & & \\
\hline $741 \mathrm{~A}-1 \mathrm{R}-1,5-6$ & 1 & 3.899 & 4.004 & 32.242 & 40.144 & & & 0.06 & \\
\hline
\end{tabular}


APPENDIX (continued).

\begin{tabular}{|c|c|c|c|c|c|c|c|c|c|}
\hline \multirow{2}{*}{$\begin{array}{l}\text { Hole, core, section, } \\
\text { interval }(\mathrm{cm})\end{array}$} & \multirow[b]{2}{*}{ Zone } & \multicolumn{4}{|c|}{ Counts $\times 10^{7}$} & \multirow[b]{2}{*}{ S.R. } & \multirow[b]{2}{*}{ D. } & \multirow{2}{*}{$\begin{array}{l}\text { Depth } \\
\text { (mbsf) }\end{array}$} & \multirow{2}{*}{$\begin{array}{c}\text { Age } \\
\text { (m.y.) }\end{array}$} \\
\hline & & Spores & Centrics & Pennates & Diatoms & & & & \\
\hline $741 \mathrm{~A}-1 \mathrm{R}-1,40-41$ & 1 & 3.082 & 2.994 & 31.344 & 37.507 & & & 0.41 & \\
\hline IR-1, $48-50$ & 1 & 3.339 & 4.118 & 37.061 & 44.518 & & & 0.49 & \\
\hline $1 \mathrm{R}-2,40-41$ & 1 & 0.014 & 0.014 & 0.128 & 0.156 & & & 1.91 & \\
\hline $1 \mathrm{R}-3,40-41$ & 1 & 0.000 & 0.000 & 0.000 & 0.000 & & & 3.41 & \\
\hline $4 \mathrm{R}-1,38-39$ & 1 & 0.000 & 0.000 & 0.000 & 0.000 & & & 24.29 & \\
\hline $4 R-2,39-40$ & 1 & 0.000 & 0.000 & 0.000 & 0.000 & & & 25.80 & \\
\hline $4 \mathrm{R}-3,37-38$ & 1 & 0.000 & 0.000 & 0.000 & 0.000 & & & 27.28 & \\
\hline $742 \mathrm{~A}-1 \mathrm{R}-1,4-6$ & 1 & 1.097 & 0.707 & 4.083 & 5.887 & & & 0.05 & \\
\hline IR-1, 40-41 & 1 & 0.000 & 0.000 & 0.000 & 0.000 & & & 0.41 & \\
\hline $1 \mathrm{R}-2,40-41$ & 1 & 0.206 & 0.240 & 0.260 & 0.706 & & & 1.91 & \\
\hline $1 R-3,40-41$ & 1 & 0.140 & 0.070 & 0.062 & 0.272 & & & 3.41 & \\
\hline $2 \mathrm{R}-1,40-41$ & 1 & 0.000 & 0.000 & 0.000 & 0.000 & & & 4.91 & \\
\hline $744 \mathrm{~A}-1 \mathrm{H}-1,1-2$ & 1 & 0.000 & 11.680 & 80.200 & 91.657 & 4.6 & 0.41 & 0.02 & \\
\hline $1 \mathrm{H}-1,35-37$ & 1 & 0.366 & 4.483 & 28.820 & 33.669 & 4.6 & 0.41 & 0.36 & \\
\hline $1 \mathrm{H}-1,85-86$ & 1 & 0.571 & 4.854 & 54.535 & 59.960 & 4.6 & 0.41 & 0.86 & \\
\hline $1 \mathrm{H}-1,135-136$ & $i$ & 0.298 & 3.877 & 50.995 & 55.170 & 4.6 & 0.41 & 1.36 & \\
\hline $1 \mathrm{H}-2,35-36$ & 1 & 0.178 & 3.025 & 22.240 & 25.442 & 4.6 & 0.73 & 1.86 & \\
\hline $1 \mathrm{H}-2,85-86$ & 1 & 0.000 & 2.093 & 13.452 & 15.545 & 4.6 & 0.73 & 2.36 & \\
\hline $1 \mathrm{H}-2,135-136$ & 1 & 0.000 & 2.626 & 7.002 & 9.627 & 4.6 & 0.73 & 2.86 & \\
\hline $1 \mathrm{H}-3,35-36$ & 1 & 0.000 & 1.571 & 5.427 & 6.999 & 4.6 & 0.76 & 3.36 & \\
\hline $1 \mathrm{H}-3,85-86$ & 1 & 0.000 & 2.825 & 4.191 & 7.016 & 4.6 & 0.76 & 3.86 & \\
\hline 744B-1H-1, 1-2 & 1 & 0.319 & 6.707 & 41.199 & 48.225 & 4.6 & 0.53 & 0.02 & \\
\hline $1 \mathrm{H}-1,40-41$ & 1 & 0.206 & 2.581 & 16.210 & 18.998 & 4.6 & 0.53 & 0.41 & \\
\hline $1 \mathrm{H}-1,90-91$ & 1 & 0.457 & 3.199 & 36.564 & 40.221 & 4.6 & 0.53 & 0.91 & \\
\hline $1 \mathrm{H}-1,140-141$ & 1 & 0.512 & 4.605 & 53.721 & 58.325 & 4.6 & 0.53 & 1.41 & \\
\hline $1 \mathrm{H}-2,40-41$ & 1 & 0.127 & 2.800 & 13.236 & 16.164 & 4.6 & 0.53 & 1.91 & \\
\hline $1 \mathrm{H}-2,90-91$ & 1 & 0.000 & 3.584 & 22.125 & 25.709 & 4.6 & 0.53 & 2.41 & 0.01 \\
\hline $1 \mathrm{H}-2,140-141$ & 1 & 0.000 & 1.714 & 8.891 & 10.605 & 4.6 & 0.53 & 2.91 & 0.01 \\
\hline $1 \mathrm{H}-3,40-43$ & 1 & 0.000 & 1.259 & 5.981 & 7.241 & 4.6 & 0.78 & 3.41 & 0.01 \\
\hline $1 \mathrm{H}-3,90-91$ & 1 & 0.189 & 2.079 & 9.263 & 11.531 & 4.6 & 0.78 & 3.91 & 0.01 \\
\hline $1 \mathrm{H}-3,140-141$ & 1 & 0.000 & 2.442 & 6.042 & 8.484 & 4.6 & 0.78 & 4.41 & 0.01 \\
\hline $1 \mathrm{H}-4,40-41$ & 1 & 0.000 & 1.413 & 6.498 & 7.911 & 4.6 & 0.78 & 4.91 & 0.01 \\
\hline $1 \mathrm{H}-4,90-91$ & 1 & 0.000 & 0.482 & 1.477 & 1.959 & 4.6 & 0.78 & 5.41 & 0.01 \\
\hline $1 \mathrm{H}-5,40-41$ & 1 & 0.102 & 3.061 & 8.876 & 12.038 & 4.6 & 0.64 & 6.41 & 0.01 \\
\hline $1 \mathrm{H}-5,90-91$ & 1 & 0.000 & 2.048 & 9.897 & 11.945 & 4.6 & 0.64 & 6.91 & 0.02 \\
\hline $1 \mathrm{H}-5,140-141$ & 1 & 0.000 & 2.207 & 9.600 & 11.806 & 4.6 & 0.64 & 7.71 & 0.02 \\
\hline $1 \mathrm{H}-6,40-41$ & 1 & 0.000 & 8.049 & 8.289 & 16.339 & 4.6 & 0.64 & 7.91 & 0.02 \\
\hline $1 \mathrm{H}-6,90-91$ & 1 & 0.000 & 5.517 & 13.241 & 18.758 & 4.6 & 0.64 & 8.41 & 0.02 \\
\hline $1 \mathrm{H}-6,140-141$ & 1 & 0.000 & 3.293 & 10.385 & 13.678 & 4.6 & 0.64 & 8.91 & 0.02 \\
\hline $1 \mathrm{H}-7,40-41$ & 1 & 0.000 & 5.253 & 11.164 & 16.417 & 4.6 & 0.45 & 9.41 & 0.02 \\
\hline $745 \mathrm{~A}-1 \mathrm{H}-1,35-36$ & 1 & 0.193 & 1.860 & 3.693 & 5.650 & 54 & 0.50 & 0.86 & 0.02 \\
\hline $1 \mathrm{H}-1,85-86$ & 1 & 0.371 & 3.573 & 8.864 & 12.808 & 54 & 0.50 & 1.36 & 0.03 \\
\hline $1 \mathrm{H}-1,135-137$ & 1 & 0.203 & 3.049 & 5.081 & 8.333 & 54 & 0.50 & 1.86 & 0.03 \\
\hline $1 \mathrm{H}-2,35-36$ & 1 & 0.014 & 0.250 & 1.263 & 1.526 & 54 & 0.50 & 2.36 & 0.04 \\
\hline $1 \mathrm{H}-2,85-86$ & 1 & 0.384 & 3.837 & 9.209 & 13.430 & 54 & 0.50 & 2.86 & 0.05 \\
\hline 745B-1H-2, $87-88$ & 1 & 0.007 & 0.757 & 1.296 & 2.059 & 54 & 0.43 & 2.38 & 0.04 \\
\hline $2 \mathrm{H}-\mathrm{CC}$ & 1 & 0.075 & 1.641 & 7.234 & 8.949 & 54 & 0.42 & 14.50 & 0.27 \\
\hline $4 \mathrm{H}-2,130-131$ & 1 & 0.030 & 0.674 & 1.520 & 2.223 & 54 & 0.45 & 26.81 & 0.50 \\
\hline $4 \mathrm{H}-3,38-39$ & 1 & 1.133 & 2.222 & 8.018 & 11.373 & 54 & 0.45 & 27.39 & 0.51 \\
\hline $4 H-3,65-66$ & 1 & 0.510 & 2.548 & 10.136 & 13.194 & 54 & 0.45 & 27.66 & 0.51 \\
\hline $4 \mathrm{H}-3,130-131$ & 1 & 0.898 & 8.680 & 42.504 & 52.082 & 54 & 0.45 & 28.31 & 0.52 \\
\hline $4 \mathrm{H}-4,38-39$ & 1 & 0.000 & 5.631 & 43.074 & 48.705 & 54 & 0.45 & 28.89 & 0.53 \\
\hline $4 \mathrm{H}-4,85-86$ & 1 & 0.200 & 3.956 & 7.436 & 11.592 & 54 & 0.45 & 29.36 & 0.54 \\
\hline $4 \mathrm{H}-4,130-131$ & 1 & 0.214 & 6.749 & 14.354 & 21.317 & 54 & 0.45 & 29.81 & 0.55 \\
\hline $4 \mathrm{H}-5,38-39$ & 1 & 0.313 & 5.314 & 15.785 & 21.411 & 54 & 0.45 & 30.39 & 0.56 \\
\hline $4 \mathrm{H}-5,85-86$ & 1 & 0.000 & 3.310 & 17.704 & 21.014 & 54 & 0.45 & 30.86 & 0.57 \\
\hline $4 \mathrm{H}-5,130-131$ & 1 & 0.717 & 6.350 & 29.397 & 36.464 & 54 & 0.45 & 31.31 & 0.58 \\
\hline $4 \mathrm{H}-6,38-39$ & 1 & 0.317 & 5.925 & 30.999 & 37.241 & 54 & 0.45 & 31.89 & 0.59 \\
\hline $4 \mathrm{H}-6,85-86$ & 1 & 0.494 & 1.836 & 16.714 & 18.505 & 54 & 0.45 & 32.36 & 0.60 \\
\hline $4 \mathrm{H}-6,130-131$ & 1 & 0.000 & 0.324 & 1.033 & 1.357 & 54 & 0.45 & 32.81 & 0.61 \\
\hline $4 \mathrm{H}-7,38-39$ & 1 & 0.012 & 0.514 & 0.368 & 0.893 & 54 & 0.45 & 33.39 & 0.62 \\
\hline
\end{tabular}



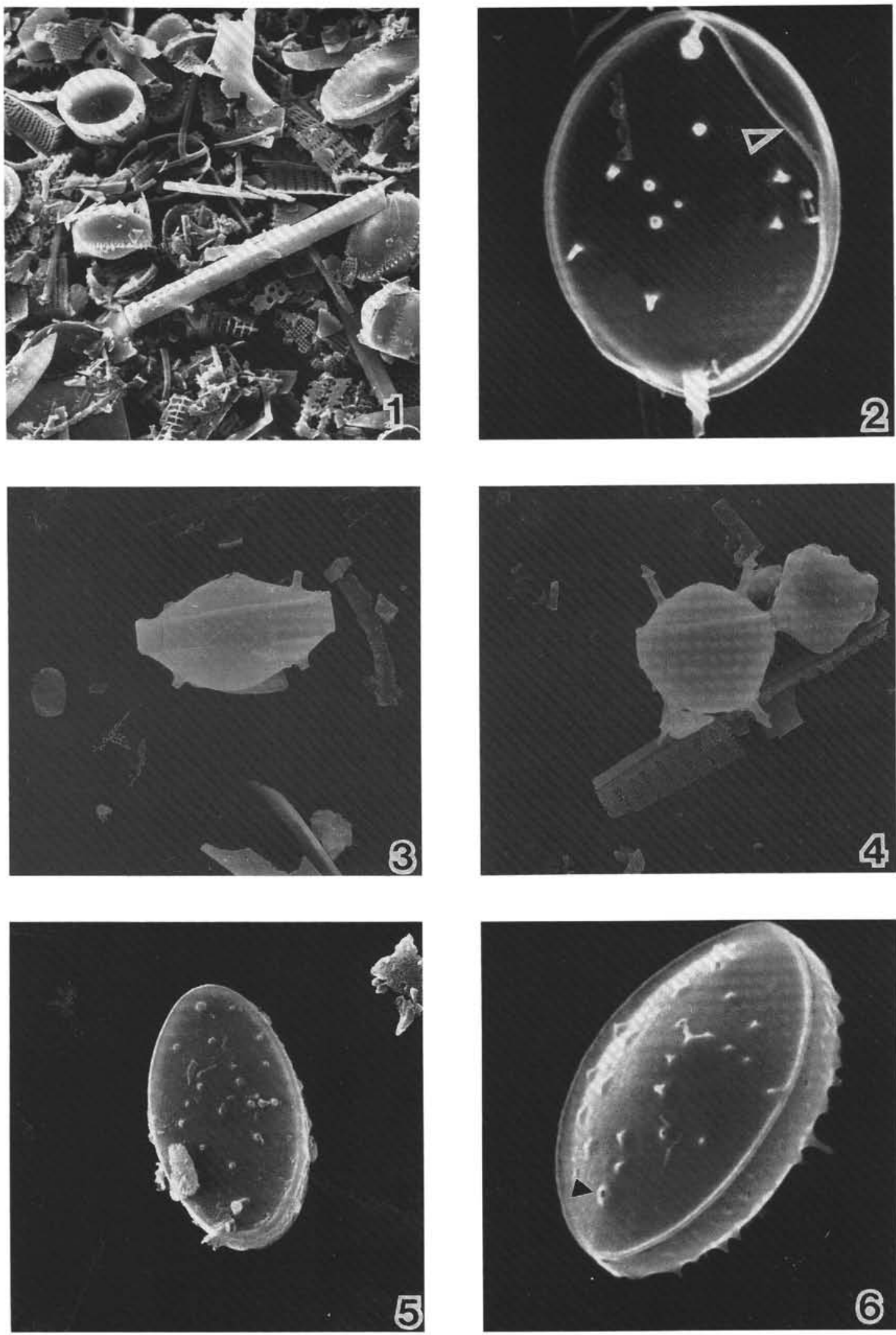

Plate 1. 1. Typical example of Chaetoceros resting spores among the broken diatomaceous fragments from Site $736(\times 2000)$. Figures $2-6$ illustrate Chaetoceros neglectus resting spores from Sample 119-736A-1H-4, 93-95 cm. 2. Resting spore, valve view. Note residual wall of vegetative cell is still present $(\times 7,500)$. 3. Girdle view, whole spore. Note that the vaulted valve faces are relatively smooth of sculpturing $(\times 3000)$. 4. Resting spore, with the two diagnostic processes on each valve. Higher vaulting is coincidental with a narrow cell width $(\times 3000)$. 5. Valve view showing numerous spines on valve face along with remnants of the two large processes $(\times 3500)$. 6. Similar valve, also showing processes along the margin of the mantle $(\times 7500)$ 

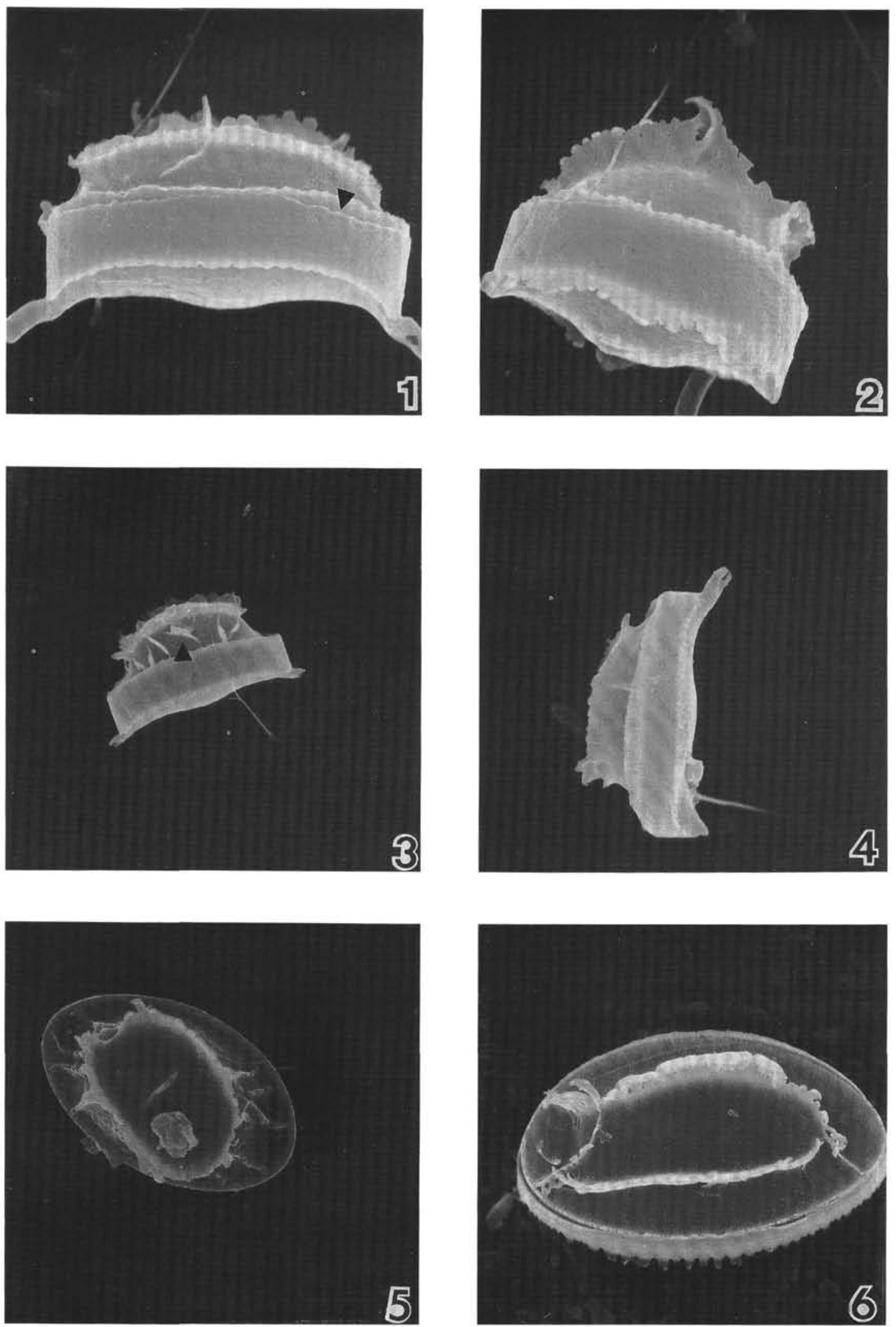

Plate 2. Figures 1-6, Chaetoceros sp. A resting spore. 1. Girdle view of spore showing remnants of parent, vegetative cell (arrow). Note the raised section of the primary valve that is relatively smooth. Elevated section appears to be a steeply vaulted with a fringe or palisade of silicon $(\times 5000)$. 2. Girdle view showing further development of fringe into a sail-like structure $(\times 5000)$. 3. Girdle view, again showing attached parent cell. Walls of the highly vaulted section are not smooth but bear raised processes, shown by arrow $(\times 2500)$. 4. Girdle view. Note asymmetry in valve height $(\times 1000)$. 5. Valve view. Top of elevated section of primary valve appears smooth, but side bears ridges. 6. Valve view. Note marginal ring of spines (arrow); other valves have appeared relatively smooth $(\times 5000)$. 

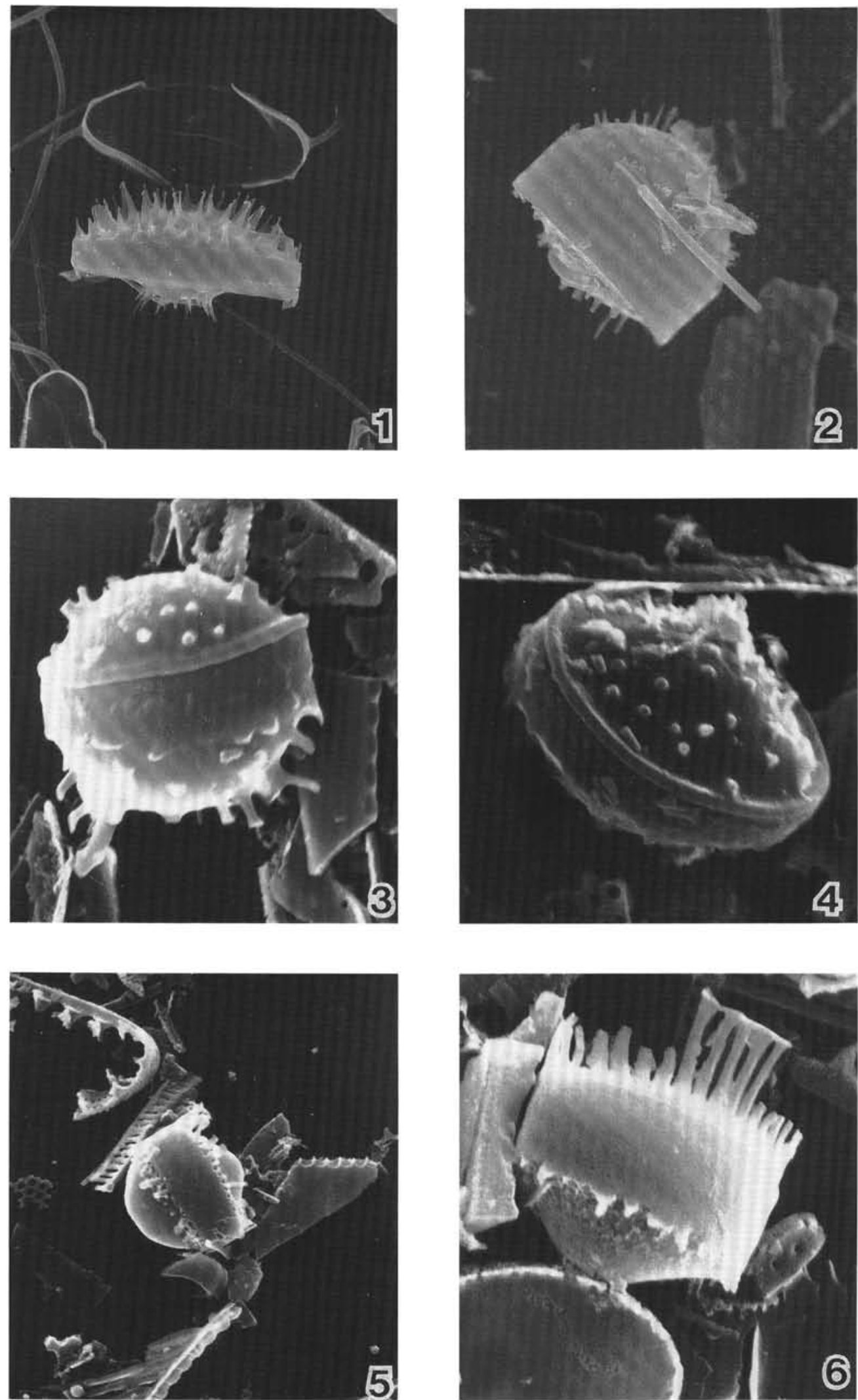

Plate 3. 1. Girdle view of Chaetoceros sp. B, whole spore. Note the broad margin and numerous spines on both valves $(\times 2000)$. 2. Girdle view of Chaetoceros sp. B, whole spore. Observe the margin appears much broader and the spines are reduced $(\times 3000)$. 3. Girdle view of Chaetoceros sp. $\mathrm{C}$, whole spore. Margins are very steep, but terminate in ridge. Both valves are moderately vaulted and bear numerous spines $(\times 7500)$. 4. View of Chaetoceros sp. C. Vaulting of valves reduced and spines appear as knobs $(\times 7500)$. 5. Girdle view of whole spore of Chaetoceros sp. D. Steep marginal wall terminating in spines on both sides. Valves appear highly vaulted and smooth $(\times 3500)$. 6. Girdle view of whole spore of Chaetoceros sp. D. Note the elongation of spines along the marginal wall. These spines may fuse, forming a palisades layer. 

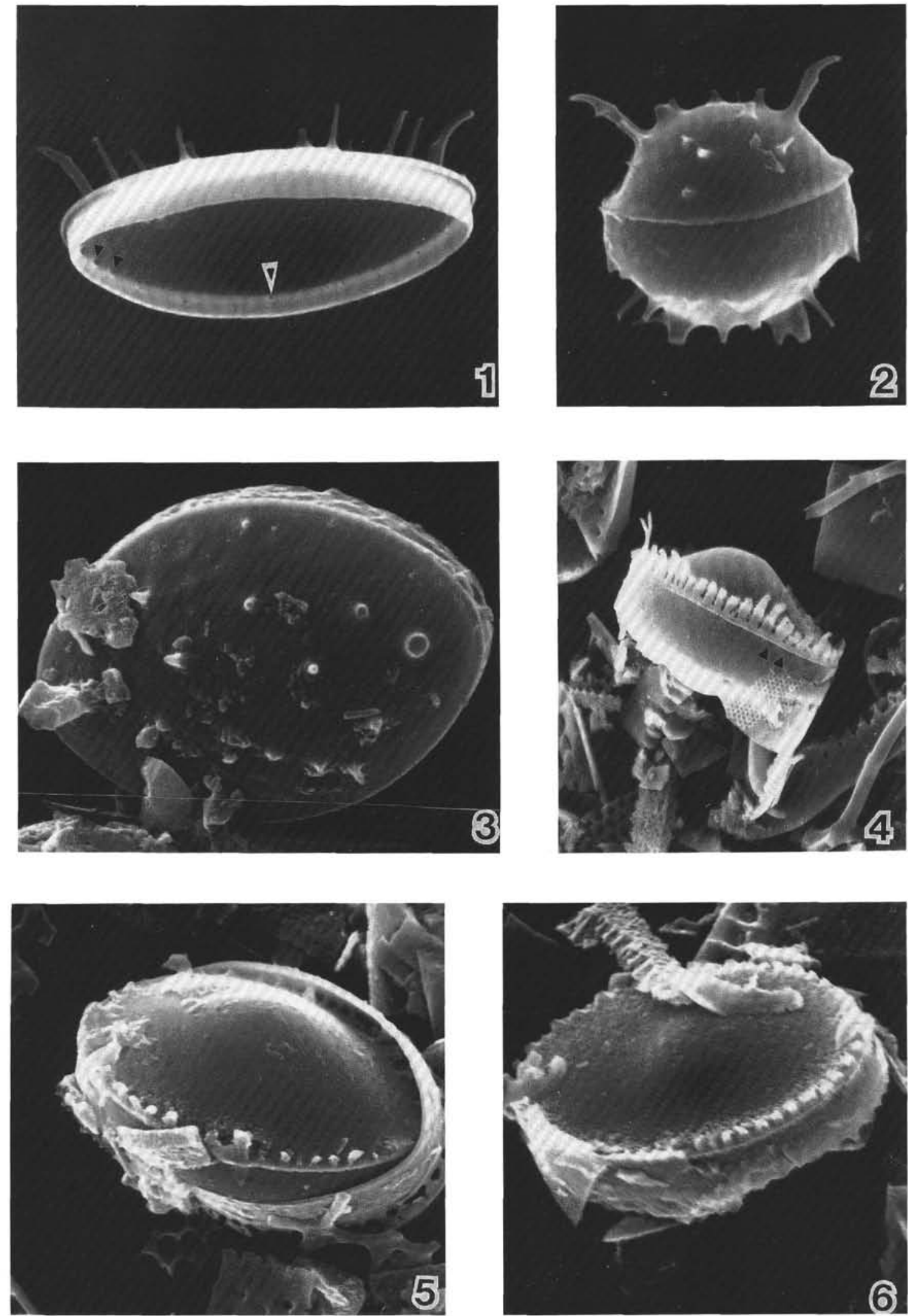

Plate 4. 1. Hypovalve of Chaetoceros neglectus resting spore. Note the two large processes and many smaller spines. Arrows denote pores along the valve flange $(\times 7500)$. 2. Girdle view of Chaetoceros neglectus spore. Whole spore showing spines on valve surface $(\times 7500)$. 3. Valve view of Chaetoceros neglectus showing numerous small spines and larger, broken processes which appear as solid silicon $(\times 7500)$. 4. Girdle view of Chaetoceros neglectus sp. E. hypovalve. Note the ring of pores on marginal flange shown by the arrows. Above this lip is a ring of short spines $(\times 5000)$. 5. Valve view of Chaetoceros sp. E. Shows separation of spore valves. Valve face appears moderately vaulted $(\times 7500)$. 6. Valve view of Chaetoceros sp. E, showing hypovalve with only a slightly vaulting. Marginal ring of spines reduced $(\times 7500)$. 